for destroying interspecies grafts, a group of immune reactions about which we at present know very little ${ }^{13,14}$.

This work was supported in part by the US Public Health Servise and by a Pennsylvania Plan scholarship. I thank Professor R. E. Billingham for his encouragement and helpful criticism and Mr George Sawchuck for technical assistance.

Department of Medical Genetics,

C. F. SHAFFER

School of Medicine,

University of Pennsylvania,

Philadelphia, Pennsylvania.

Received May 30; revised Angust 11, 1969.

${ }^{1}$ Lance, E. M., and Medawar, P. B., Lancet, i, 1174 (1968).

${ }^{2}$ Loeb, L., in The Biological Basis of Individuality, 116 (Thomas, Springfield, 1945). ${ }^{3}$ Monaco, A. P., Wood, M. L., Gray, J. G., and Russell, P. S., J. Immunol.,
96, 229 (1966).

${ }^{4}$ Levey, R. H., and Medawar, P. B., Proc. VS Nat. Acad. Sci., 56, 1130 (1966).

¿Gray, J. G., Monaco, A. P., Wood, M. I., and Russell, P. S., J. Immunol. 96, 217 (1966)

${ }^{6}$ Amos, D. B., and Peacocke, N., in Proc. Ninth Cong. Europ. Soc. Haemat. (Lisbon), 1132 (S. Karger, Basel and New York, 1963).

- Billingham, R. E., in Transplantation of Tissues and Cells (edit. by Billingham, R. E., and Silvers, W. K.), 1 (Wistar Inst. Press, Philadelphia, 1961).

${ }^{8}$ Hildemann, W. H., and Walford, R. I., Ann. NY Acad. Sci., 87, 56 (1960).

- Waksman, B. H., Lab. Invest., 12, 46 (1963).

${ }^{10}$ Palm, Joy, Silvers, W. K., and Billingham, R. E., J. Heredit., 58, 40 (1967)

${ }^{11}$ Starzl, T. E., Marchioro, T. L., Porter, K. A., Iwasaki, Y., and Cerilli, G. J., Surg. Obstet. Gynec., 124, 301 (1967).

12 Starzl, T. F., Porter, K. A., Iwasaki, Y., Marchioro, T. L., and Kashiwagi, N., in Antilymphocytic Serum, 4 (Ciba Foundation Symp., Little, Brown and Compauy, Boston, 1967).

${ }^{13}$ Algire, G. H., Weaver, J. M., and Prehn, R. T., Ann. NY Acad. Sci., 64, 1009 (1957).

14 Hašek, M., Folia Biol., 8, 57 (1962).

\section{Therapy of Transplantable Mouse Leukaemias with Antileukaemia Sera}

THE therapy of leukaemias by the administration of heterologous antisera has been tested both in experimental animals ${ }^{1-5}$ and in patients $s^{6,7}$, but the results have been variable and confusing. This article seeks to explain these discrepancies and indicates how positive results might be obtained.

Leukaemia cells are malignant forms of lymphocytes, so that antileukaemia sera are closely related to antilymphocyte sera (ALS). Recently, ALS has been used widely for prolongation of allograft survival ${ }^{8-11}$ and some of this experience is directly applicable to trials of antileukaemia sera. We have previously studied in vitro the specificities of rabbit antisera to various types of mouse lymphocytes ${ }^{12}$. Because antileukacmia sera were slightly more specific against leukaemia cells than was ALS, antileukaemia sera were used exclusively. though this does not exclude the possibility that ALS might also be effective.

Three congenic leukaemias were transplanted intraperitoneally in congenic mice: Gardner lymphosarcoma 6C3HED of $\mathrm{C} 3 \mathrm{H}$ strain ${ }^{13-15}$, transplanted in the low mammary tumour substrain $\mathrm{C} 3 \mathrm{HeB} / \mathrm{FeJ}$; lymphocytic leukaemia L1210 of DBA/2J mice m-15; $^{13}$ and leukaemia RA5 of AKR/J mice ${ }^{13-15}$. Groups of three or more rabbits were hyperimmunized by two courses of injections, each of which consisted of a single subcutaneous injection (intramuscular injections have since been found to be preferable) of approximately twenty million leukaemia cells in com. plete Freund-McDermott adjuvant, followed by five to seven intravenous injections of approximately thirty million viable cells in isotonic saline, given twice weekly. Rabbits were bled 7 to 10 days after the last injection. Antisera were inactivated for 30 min at $56^{\circ} \mathrm{C}$ and stored at $-20^{\circ} \mathrm{C}$.
Serial doubling dilutions of antisera were titred against leukaemia cells by immune cytolysis ${ }^{16,17}$. Because potency is proportional to the reciprocal of titre, it was conveniently expressed as 100/cytolytic titre. For therapy experiments, potency units were used that depended on the volume administered, as well as on the potency of the antiscrum. Potency units were calculated as 100/cytolytic titre $\times$ volume of antiserum injected (mI.). For therapy trials in vivo, we used the standard assay system (Table 1) considered to be one of the most helpful for selection of clinically useful chemotherapeutic materials ${ }^{18}$. Treatment was only effective when many units of cytolytic potency were administered, but antisera with high cytolytic potency were usually highly toxic: within $1 \mathrm{~h}$ after intraperitoneal injection of $0.1 \mathrm{ml}$., the erythrocyte count fell sharply, massive haemolysis occurred and death occurred within a few hours. An amount of antiserum that killed 15 per cent of the mice gave the maximum depression of haematocrit (to 10 per cent of its normal value) $30 \mathrm{~h}$ after injection. The hacmatocrit returned to 50 per cent of its original value after 6 days, and to 90 per cent on the tenth day. Mice that survived 4 days after a single injection, or after a series of injections, rarely died later.

Table 1. In vivo TESTS OF $\gamma$-GLOBULIN FROM A RABBIT ANTISERUM PREPARED AGAINST GARDNER LEUKAEMIA CELLS

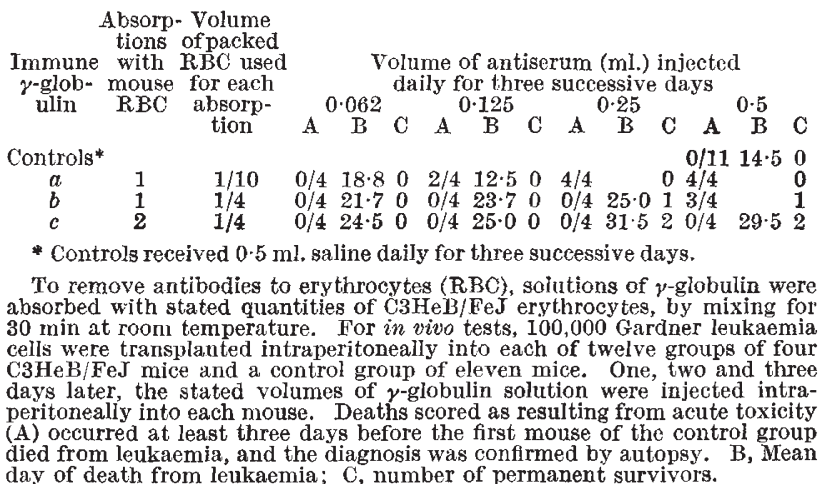

The acute toxicity of potent antileukaemia sera was progressively removed by absorptions with mouse erythrocytes (Table 1). These absorptions greatly decreased antibody activity against erythrocytes. For the three immune $\gamma$-globulin preparations $a, b$ and $c$ (Table 1), there were sharp reductions in haemagglutination potency ${ }^{19}$ (from 760 , to 190 and to 24), in haemolytic potency ${ }^{19}$ (from 3,200 , to 2,080 and to 560 ), and in potency of complement $C^{\prime}$ fixation $^{12}$ by mouse erythrocytes (from 1,280 , to 304 and to 0 ), respectively. In contrast, antibody activity against leukaemia cells was only slightly decreased. For the same series of absorptions (Table 1), this decrease was less than 25 per cent, as determined both by immune cytolysis ${ }^{16,17}$ and by $C^{\prime}$ fixation ${ }^{12}$ against Gardner leukaemia cells.

The results indicate that antibodies to mouse erythrocytes are responsible for the acute toxicity of potent hyperimmune antileukaemia sera ${ }^{20,21}$. The effects of such antisera are adequately predicted by the number of units of haemagglutination potency administered (Fig. 1). Below a certain threshold, such sera are not acutely toxic. Therapy experiments indicate that prolongation in the lifespan of mice increases in direct proportion to the total units of cytolytic potency injected on successive days (Fig. 2). With Gardner leukaemia, the threshold for therapeutic effect occurred at relatively few units of cytolytic potency; when many units were administered, permanent survivors were obtained in some experiments (Fig. 2). In contrast, tho threshold was much higher for leukaemia L1210; the number of cytolytic potency units could not be sufficiently increased to achieve long term survival of a single DBA/2J mouse inoculated with 
L1210 cells in the present assay conditions. Similar results were obtained with leukaemia RA5.

Even after absorption of highly potent antisera with mouse erythrocytes, the doses administered could not be increased without producing chronic toxicity. This accounts for the absence of more permanent survivors (Fig. 2). One possible reason for the residual toxicity is erythrocyte destruction by antibodies directed against antigens (such as of $\mathbf{H}-2$ genotype), which are present in high concentration on lymphoid or leukaemia cells; and in lower ${ }^{22}$, yet ample ${ }^{23}$, concentrations on erythrocytes. Alternatively, residual toxicity may result from a reaction against normal lymphoid tissue. In this respect, antileukaemia sera resemble ALS as depressants of circulating lymphocytes and hypersensitivity reactions $\mathrm{s}^{8-11,24,25}$. The remarkable lack of toxicity of ALS as an immunodepressant ${ }^{26,27}$ may be attributed to its use in comparatively low doses and potencies.

Several objections can be raised against the use of antileukaemia sera for therapy of leukaemias. First, continued administration of an immunosuppressant may permit the emergence of neoplasms. Experience of this in humans ${ }^{28}$ has been confirmed in experimental animals ${ }^{29,30}$. No enhancement in growth of leukaemias was, however, noted by us. This accords with previous findings ${ }^{31,32}$ that leukaemias are difficult to enhance. Second, by analogy with ALS, a host antibody response to continued injections of antileukaemia sera can be expected ${ }^{33,34}$. This host response may prevent the continued effectiveness of repeated courses of treatment. Third, complete eradication of a tumour may depend on the host's ability to respond to the tumour-specific (foreign) antigens present on the tumour cells, for therapentic agents usually reduce the number and viability of tumour cells, but do not eliminate them entirely ${ }^{35}$. If the therapeutic agent is an immunodepressant, destruction of the remnant of tumour cells may be impossible unless the relevant lymphoid cells can regenerate faster than the tumour can grow again. Finally, the isogenicity of the assay system involving L1210 cells may be questioned ${ }^{36}$, though some degree of host response, albeit weak, to turnourspecific antigenicity has been found virtually in every syngeneic tumour system investigated in detail "35. "True" isogenicity of the assay system may therefore be less important than a good correlation with clinical findings.

The findings explain previous conflicting results relating to the therapeutic use of antileukaemia sera ${ }^{1-7}$; positive results can only be expected when the highest possible number of eytolytic potency units is administered. If an

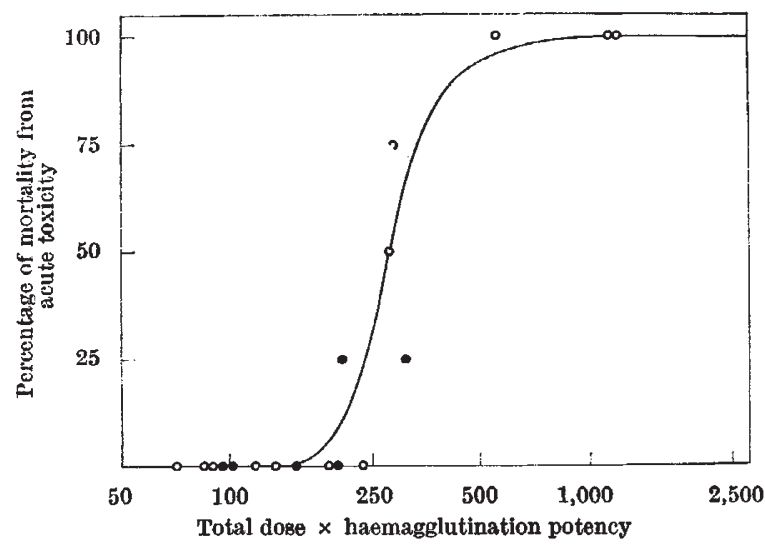

Fig. 1. Relationship between units of haemagglutination potency injected into $\mathrm{C3HeB} / \mathrm{FeJ}$ mice and mortality. The dose of antiserum (ml.) was divided into three intraperitoneal injections given on successive days. Haemagglutination potency is 100/haemagglutination titre, where haemagglutination titre is the lowest final concentration of antiserum (per cent) at which definite agglutination of a standardized suspension of mouse erythrocytes is still seen ${ }^{18}$. Each point represents results obtained with four mice. Results from two sets of experiments ( $O$ and

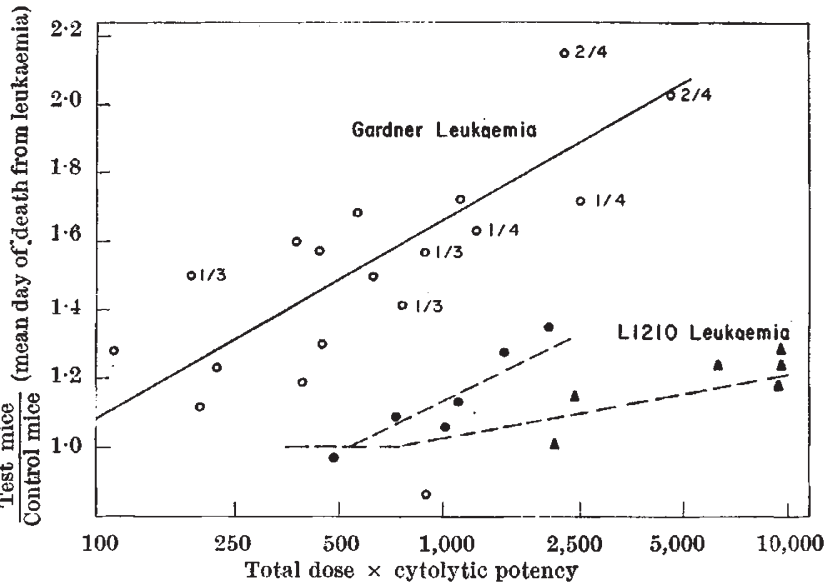

Fig. 2. Relationship between units of cytolytic potency injected and the survival time of test compared with control mice. All mice received 100,000 leukaemia cells at the start of a therapy experiment (see text). Each point represents a group of three or more mice. 0 , Experiments with Gardner leukaemia and antiserum injections on 3 successive days; , L1210 leukaemia and antiserum injections on 3 or 4 successive days; $\boldsymbol{A}$, L1210 leukaemia and injections on $5-10$ successive days. Higures (No. of permanent survivors/No. of nice in the groul) are given only for groups in which some mice survived to the end of their natural lifespan.

antiserum is not potent enough or too little is injected, little or no therapeutic effect can be expected. The acute toxicity of highly potent antileukaemia sera is the result of anti-erythrocyte antibodies; these are removed by absorptions with mouse erythrocytes. To avoid production of such antibodies, cell suspensions used for immunization should be as free of erythrocytes as possible.

This investigation was supported by a US Public Health Service research grant from the National Cancer Institute and a grant from the American Cancer Society.

ARNOLD E. ReIF

Chung-Ai H. KIal

Department of Surgery.

Tufts University School of Medicine,

Boston City Hospital,

Boston, Massachusetts.

Received June 6; revised August 4, 1969.

${ }^{1}$ Mohos, s. C., and Kidl, J. (t., J. Exp. Hed., 105, 233 (1957).

${ }^{2}$ Levi, E., Golden, R., Zerubavel, R., and Fisher, J., Cancei Res., 26. 659 (1966).

3 Schabel, jun., F. M., Skipper, H. E., Laster, jun., W. R., and Thompson, S. A., Cancer Chem. Rep., 50, 55 (1966).

${ }^{4}$ Bremberg, S., Klein, E., and Stjernwärd, J., Cancer Res., 27, 2113 (196i).

'Miller, D. G., Moldovanu, G., Kaplan, A., and Tocei, S., Cancer, 22, 1192 (1968).

'Lindstrom, G. A., Acta Medica Seand. Suppl., 22, 1 (1927).

'Brittingham, T. E., and Chaplin, jun., H., Cancer, 13, 412 (1960).

${ }^{8}$ Waksman, B. H., Arbouys, S., and Arnason, B. G., J. Exp. Med., 114. 997 (1961).

Wolstenholme, G. E. W., and O'Connor, M., Antilymphocytic Serum (Little, Brown and Co., Boston, 1967).

in Advances in Transplantation (edit. by Dausset, J., Hamburger, J., and Itathe, f.) 103 (Williams and Wilkins, Baltimore, 1968).

${ }^{31}$ Scientific Forum on Heterologous Antisera, Transplantation Proc. 1. 403 (1969).

${ }^{12}$ Asakuma, R., and Reif, A. E., Cancer Res., 28, 707 (1968).

${ }^{13}$ Gardner, W. U., Dougherty, T. F., and Williams, W. L., Cancer Res., 4, 73 (1944).

14 Law, I. W., Dunn, T. B., Boyle, P. J., and Miller, J. H., J. Nat. Cancer Inst., 10, 179 (1949).

15 Reif, A. E., and Allen, J. M. V., J. Exp. Med., 120, $413(1964)$

${ }^{16}$ Reif, A. E., and Norris, H. J., Cancer Res., 20, 1235 (1960).

${ }^{17}$ Reif, A. E., J. Immunol., 89, 849 (1962).

${ }^{18}$ Leiter, J., Abbott, B. J., and Schepartz, S. A., Caneer Res. Suppl., 32, 1093 (1964).

29 Reif, A. E., McVety, L. M., and Klein, E. R., J. Immunol., 90, 24 (1963).

20 Reif, A. E. Kim, C.A. H., Asakuma, R., Sheahan, D. G., and Culley, C.A. Proc. Amer, Assoc. Cancer Res., 9, 59 (1968).

${ }^{21}$ Wood, M. L., and Vriesendorp, H. M., Transplantation, 7, 522 (1969).

${ }^{22}$ Heberman, R., and Stetson, jun., C. A., J. Exp. Med., 121, 533 (1965).

${ }^{23}$ Snell, G. D., and Stimpfling, J. H., in Biology of the Laboratory Mouse (edit, by Green, E. L.), 457 (McGraw-Hill, New York, 1966).

${ }^{24}$ Witz, I., Yagi, Y., and Pressman, D., Proc, Soc. Exp. Biol. and Med., 12\%, 562 (1968). 
${ }^{25}$ Tyler, R. W., Everett, N. B., and Schwarz, M. R., J. Immunol., 102, 179 (1969)

${ }^{26}$ Levey, R. H., and Medawar, P. B., Proc. US Nat. Acad. Sci., 56, 1130 (1966).

"7 Medawar, P. B., The Sciences, 7, 25 (1967).

${ }^{28}$ Russell, P. S., Transplantation Proc., 1, 659 (1969).

28 Deodhar, S, D., and Crile, jun., G., Cancer Res., 29, 776 (1969).

${ }^{30}$ Fisher, B., Soliman, O., and Fisher, E. R., Proc. Soc. Exp. Biol. and Med., $131,16(1969)$

${ }^{81}$ Kaliss, N., Cancer Res., 18, 992 (1958).

${ }^{32}$ Ann. NY Acad. Sci., 129, 155 (1966).

${ }^{33}$ Lance, E. M., and Dresser, D. W., Nature, 215, 488 (1967).

${ }^{84}$ Jasin, H. E., Lourie, S. H., Currey, H. L. F., and Ziff, M., J. Immunol., 100,

${ }^{35}$ Klein, G. E., Fed. Proc. (in the press).

${ }^{38}$ Mihich, E., Cancer Res., 29, 848 (1969).

\section{In vivo Studies of the FBJ Murine Osteosarcoma Virus}

Finkel et al. ${ }^{1}$ have isolated a virus from a spontaneously occurring osteosarcoma in a 260 day old $\mathrm{CF}_{1} / \mathrm{Anl}$ mouse. This virus (FBJ) was shown to induce tumours histologically similar to the original tumour from which the virus was isolated. Here we describe further studies of this virus.

Viral concentrates of tumours induced by the FBJ virus in NIH Swiss mice were made ${ }^{2}$ and $0.1 \mathrm{ml}$. of the resulting solution was used as an inoculum for host range and neutralization studies. Newborns of seven strains of mice, approximately twenty per strain, were tested for susceptibility to FBJ virus. Using tumour incidence by day 40 as a measure of relative viral susceptibility, three patterns were noted: highly susceptible, 90-100 per cent, NIH Swiss and CFW; moderately susceptible, $40-45$ per cent, $\mathrm{CF}_{2}, \mathrm{AKR} / \mathrm{J}, \mathrm{C}_{6}, \mathrm{Br}$, and $\mathrm{Balb} / \mathrm{c}$; and weakly susceptible, 10 per cent, $\mathrm{C}_{57} \mathrm{Bl}$. These animals were observed for an additional 160 days and no significant change from the pattern at 40 days was noted (Fig. 1). The tumours were palpably very hard, with the consistency of bone tissue, and always located subcutaneously at or near the sight of inoculation. The spleens were generally enlarged, but were not otherwise different from the spleens of the uninoculated control $\mathrm{CF}_{1}$ mice. All tumours had the histological characteristies of mesenchymal sarcomas including fibrosarcomas, fibrosarcomas with osteoblastic cells, and well differentiated osteosarcomas with bone formation, and some of the tumours showed areas representative of all these histological types. No tumours were induced in

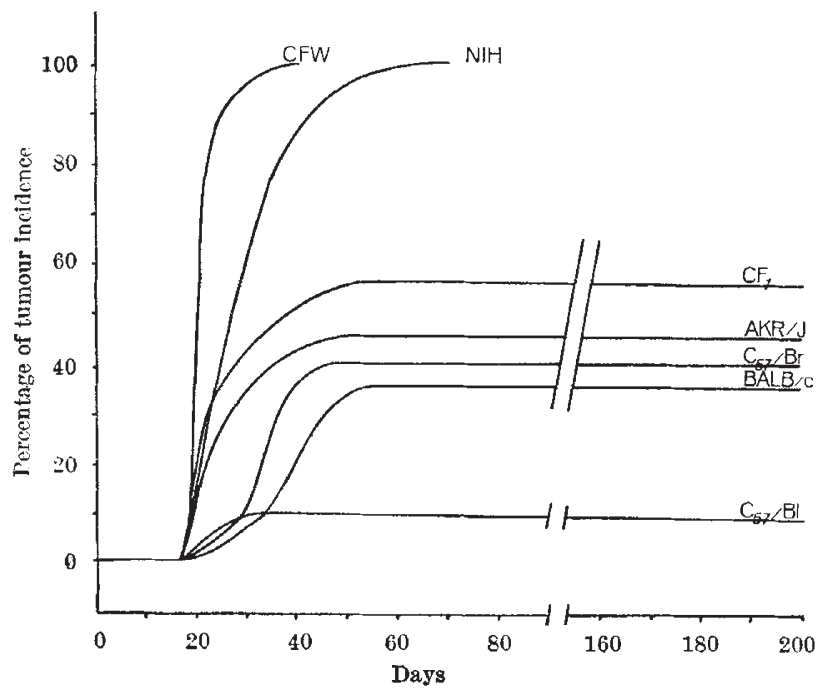

Fig. 1. Host range of FBJ virus as measured by percentage of tumour incidence in seven strains of mice. any of fifty newborn NIH hamsters or fifty newborn Fisher rats during a 200 day observation period.

Complement-fixation tests were carried out by the microtitre procedure ${ }^{3}$. Antigens were prepared as 20 per cent $\mathrm{w} / \mathrm{v}$ homogenates of spleens, thymuses and tumours. Sera reactive with the group-specific (gs) and envelope antigens of the murine leukaemia viruses (MuLV) were obtained from Fisher rats bearing M-MSV transplant tumours ${ }^{4}$. All FBJ-induced tumours were positive in the complement-fixation test and thus contain the MuLV gs antigen. Spleen preparations were also always positive but generally had two to four-fold lower titres than tumours. Thymus preparations were only occasionally positive.

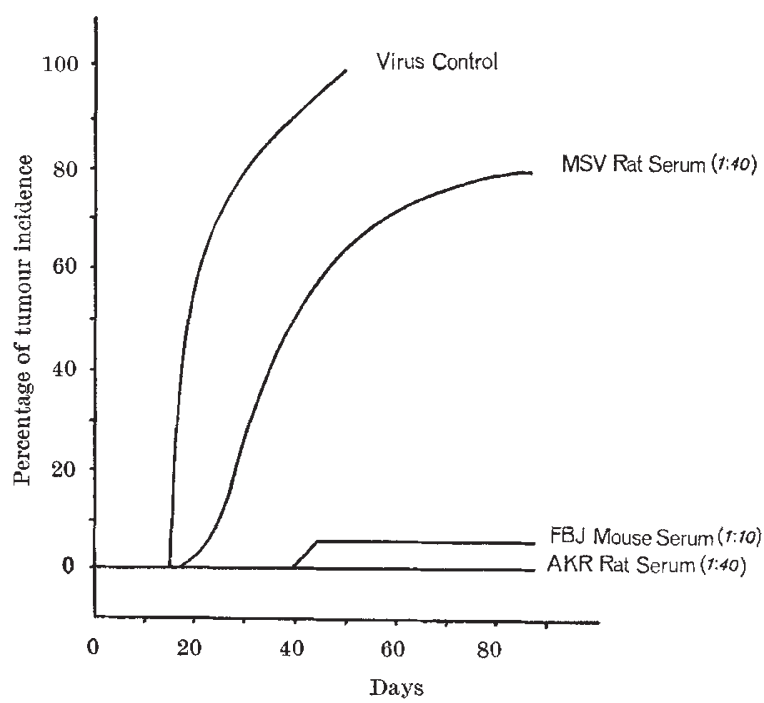

Fig. 2. Neutralization studies of $F B J$ virus as measured by percentage of tumour incidence in NIH Swiss mice, with MSV rat sera, AKR rat sera and FBJ mouse sera. The rat antisera were used at a $1: 40$ dilution to allow discrimination between FMR and Gross-type viruses).

Three sera were tested for the ability to prevent tumours in NIH Swiss mice: serum from Fisher rats bearing an AKR lymphosarcoma with high neutralizing antibody titres to Gross passage A and AKR viruses and low neutralizing titres to Friend, Moloney and Rauscher viruses; serum from Fisher rats bearing M-MSV trans. plant tumours which has high neutralizing titres to Moloney virus and very low neutralizing titres to Gross passage A and AKR viruses (ref. 4 and unpublished results of J. W. Hartley); and serum from a tumour-bearing NIH Swiss mouse inoculated with FBJ virus. Control sera were obtained from normal weanling NIH Swiss mice and Fisher rats. The virus control induced 100 per cent tumours in 50 days. AKR rat serum completely prevented tumour formation in sixteen animals during the 87 day test period. Serum from the mouse bearing the FBJ virus-induced tumour also successfully prevented tumour induction; only one tumour occurred in fourteen inoculated animals. In contrast, M-MSV rat serum only slightly reduced tumour incidence; ten out of fifteen inoculated animals had tumours in 50 days and twelve out of fifteen had tumours by 87 days (Fig. 2).

The presence of the group-specific complement-fixing antigen establishes that the FBJ virus is a member of the murine leukaemia viruses or perhaps more aptly called the murine C-type RNA virus. The neutralization data establish that it is a member of the Gross $(G+)$ or "wild" type subgroup as opposed to the FMR subgroup. This is consistent with the previous findings that all field isolates of the C-type RNA viruses are of the Gross type ${ }^{4,5}$. 